\title{
Experimental Study of Performance and Emission Characteristics of Diesel Engine with Palms Bio-Diesle Blends
}

\author{
Suvanjan Bhattacharyya ${ }^{1 *}$, Vivek Kumar Roy ${ }^{2}$, Shivam Singh Bhadauria ${ }^{2}$, Susmita Sen $^{2}$ and \\ Aritra $\mathrm{Saha}^{3}$ \\ ${ }^{* 1}$ Mechanical Engineering Department, MCKV Institute of Engineering, Liluah, Howrah. West \\ Bengal, India \\ ${ }^{2}$ Mechanical Engineering Department, Seacom Engineering College, Howrah, West Bengal, \\ India \\ ${ }^{3}$ Electronics and Communication Engineering Department, Saroj Mohan Institute of Technology, \\ Hooghly, West Bengal, India.
}

Email: suvanjanr@gmail.com

\begin{abstract}
Compression ignition engines are ubiquitous and quite popular in the automobile industry today. Many vehicles used today run on compression ignition engines. Considering the significant market presence of $\mathrm{CI}$ engines, this experiment aims to looks to investigate and possibly improve the effect a certain fuel blend has on CI engine parameters. In particular, the endeavor of this project is to study the effect on various loading conditions of a CI engine running on palm oil blended (D90A10, D60A40, D80A20, D70A30, D50A50, D40A60) with conventional diesel. The comparative measurements of CO2 and NOX have been stated and analyzed, along with BSFC and brake power. The results showed that blend of biodiesel D90A10 showed average increase in brake power than diesel.
\end{abstract}

Keywords: 4-stroke engine, Engine load, Compression engine, Palm oil, NOx emission.

\section{INTRODUCTION}

Environmental worries have increased regarding vehicular toxic waste. Many administrations have ignored this issue which has been considerably contributing to climate change. The investigation carried out in this area focus on improving efficiencies and limiting emission intensities. Biodiesel offers a noble solution to the above-mentioned difficulties due to its similar properties to conventional diesel. Palm oil is a kind of bio-diesel which is a good alternative to conventional diesel which is straining the crude oil reserves of the world. Additionally, it is also found to be environment friendly [1]. Yet, compared to diesel, palm oil has some unwanted property deficiencies like higher viscosity, density and lower volatility which affect its claim as a perfect alternative [2]. Such properties cause the palm oil to evaporate slowly comparison to conventional diesel. This means that the oil mixes with air and causes combustion efficiency to suffer. Thus the engines run on peanut oil record low performance [3-5]. Apart from that, a particular day engine test had done on peanut oil shows several other side-effects as deposit formation, carbon build up and lubricating oil contamination. It was quite clear then that peanut oil cannot be used in isolation to run engines. Rather a blend of peanut oil with conventional diesel would be more near to the purpose [6-9]. Blending could mitigate these side-effects. In order to improve the volatility of vegetable oil they can be heated, however their molecular structure remains the same. Experiments have shown that if vegetable oils are converted to esters then the aforementioned problems are significantly dealt with [10-15].

In this experiment the aim is to investigate the performance of a biodiesel. The biodiesel used for this purpose is palm. The objective is to know the properties of recently formed biodiesel mixture and the variations in properties when mixed with diesel in different proportions. Also, to examine the variations in emissions and performance characteristics of a CI engine while operating biodiesel blends.

\section{EXPERIMENTAL SET UP}

Fig. 1 shows the experimental set up. The test was conducted at various loads resulting in variation of speed. On the engine head piezoelectric pressure transducer and a crank angle encoder are mounted which measures the combustion pressure and the analogous crank angle. The pressure transmitter is fixed with a piezoelectric sensor and an integrated charge amplifier and the output shaft of the eddy current dynamometer is attached to a strain gauge type load cell which would measure the applied load to the engine. 


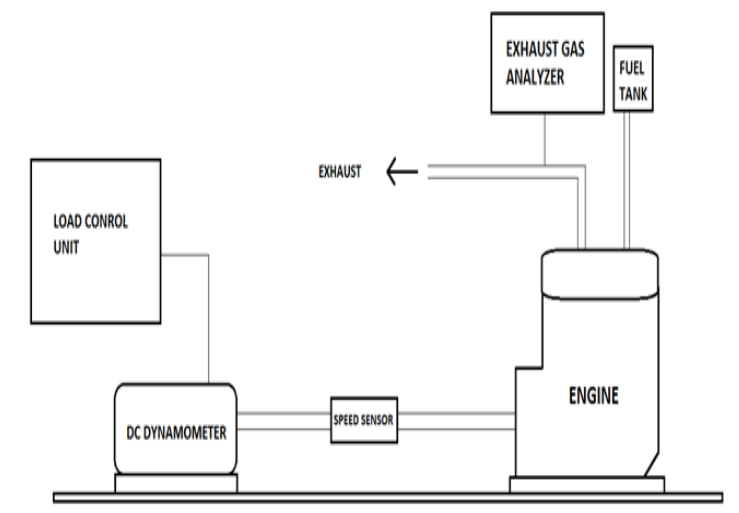

Figure 1. Schematic diagram of experimental setup

The basis of fuel consumption was mass consumption. The length of the pin projected into the combustion chamber gives the clearance volume. The experiments are carried out at various loads 100, 500, 1000, 1500, 2000, 2500, 3000 watts. The variation of total fuel consumption, engine power and the BSFC of engine are studied at different speed of the engine.

$C . R=\frac{S . V+C . V}{C . V}$

where,

S.V. $=$ Swept volume $=\pi \times(\text { Radius of Bore })^{2} \times$ Stroke

C.V. $=$ Clearance volume $=$ H.V. + D.C.V. + G.V.- E.D.V

where,

H.V. = Head Volume

D.C.V. $=$ Deck Clearance Volume $=\pi \times(\text { Radius of bore })^{2} \times$ Deck clearance

G.V. $=$ Gasket Volume $=\pi \times(\text { Radius of bore })^{2} \times$ gasket thickness

\section{BIODIESEL BLENDS PREPARATION}

The ready blends had a proportion of palm biodiesel and different proportion of diesel. To know the result of biodiesel, significant amount of biodiesels is used in blending. As par Government policy the blended biodiesel were selected. For nomenclature, D represents diesel, A represents blended biodiesel. The prepared blends were D90A10, D60A40, D80A20, D70A30, D50A50 and D40A60.

\section{RESULTS AND DISCUSSION}

The power output from the engine is known as brake power (BP). Fig. 2 shows the variation in brake power of biodiesel with variations of loads. From the Fig. 2 one can see that D90A10 sample biodiesel increases in brake power than the other tested biodiesel and conventional diesel. Also D60A40 and conventional diesel ruled the brake power at various loading conditions. The reasons for low brake power are poor combustion of fuels, which can happen due to atomization process of fuels.

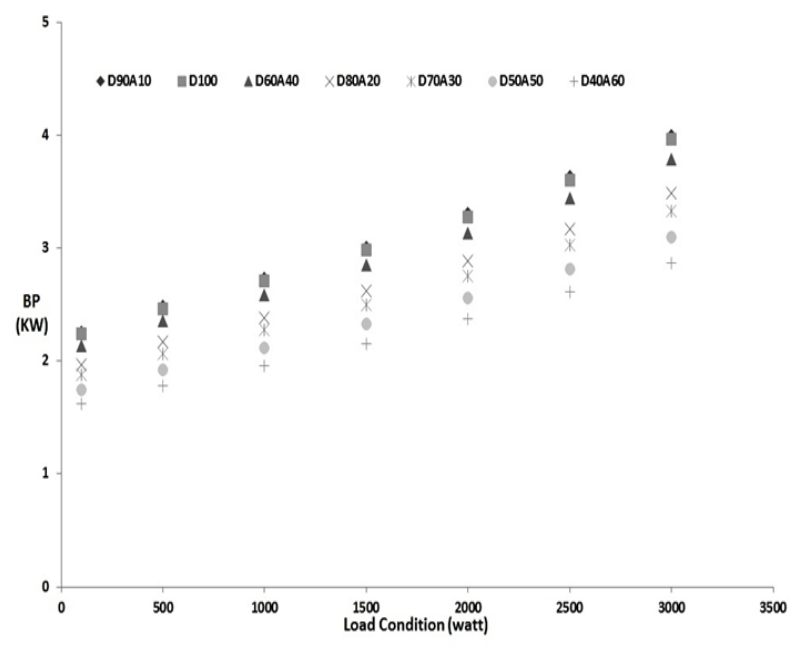

Figure 2. Variation of brake power with load conditions

BSFC is the measurement of fuel mass consumption in kilogram per unit of work done by the engine. The specific fuel consumption of D40A60 sample biodiesel is lower compared to all other fuels at various loading conditions as shown in Fig 3. Fuel density and heating value of the fuels could be the reason behind it. Sample biodiesel D70A30 has the higher energy compared to all the test fuels. From Fig 3 one can conclude that minor calorific value of greater biodiesel blends sample also plays its part in improved the values of BSFC.

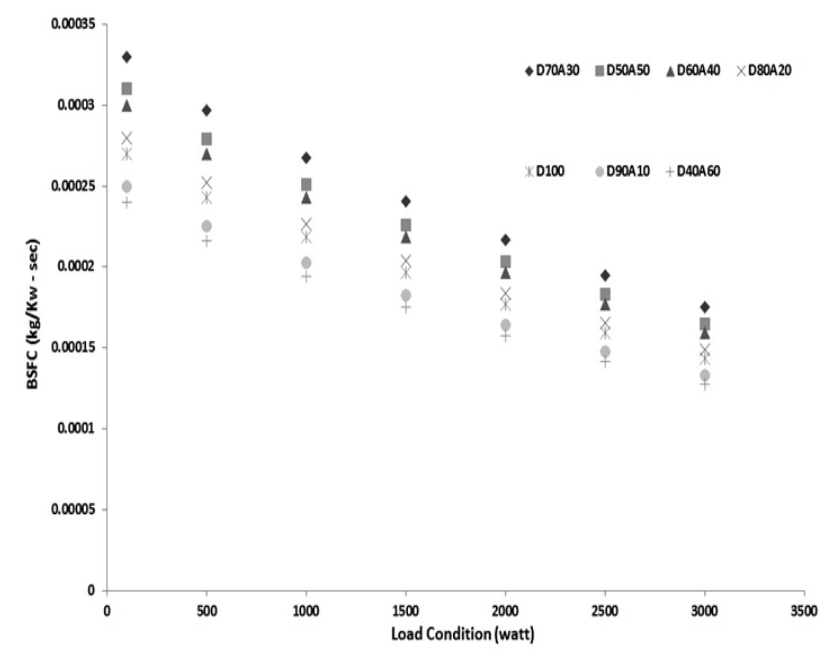

Figure 3. Variation in brake specific fuel consumption with load conditions

Fig. 4 shows the variation of $\mathrm{CO}_{2}$ emission with various engine loads. $\mathrm{CO}_{2}$ increase with the increase of engine loads is attributed to incomplete combustion and inadequate supply of oxygen. One can see from the Fig 4 that biodiesel sample D90A10 has the lowest emission and sample D40A60 has the highest emission than the other test fuels. It can also been seen that lower blends of biodiesel combust more efficiently than higher biodiesel blends. 


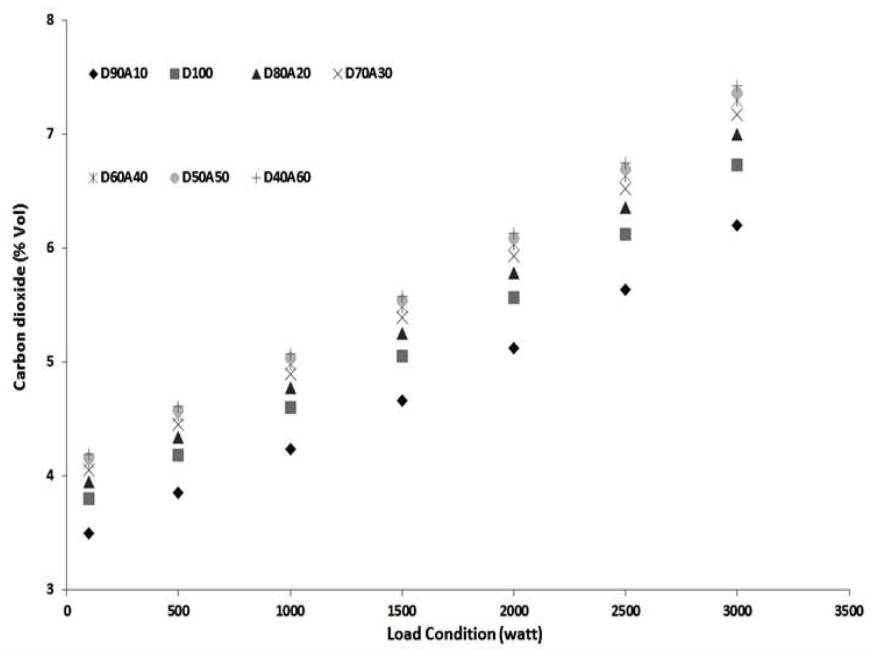

Figure 4. Variation in $\mathrm{CO}_{2}$ emissions with varying load conditions

Fig 5 demonstrates the variation of $\mathrm{NO}_{\mathrm{x}}$ with different engine loads. As it appears from the figure, the $\mathrm{NO}_{\mathrm{x}}$ emission for diesel and other blended fuels increase with the increase of engine loads. Biodiesel blends substantially increased the $\mathrm{NO}_{\mathrm{x}}$ emissions as compared to conventional diesel tested. The values for D60A40 closed to around $12 \%$ above the $\mathrm{NO}_{\mathrm{x}}$ emissions caused by conventional tested diesel. The reduction of $\mathrm{NO}_{\mathrm{x}}$ is one of the most important aims of engine performance researchers.

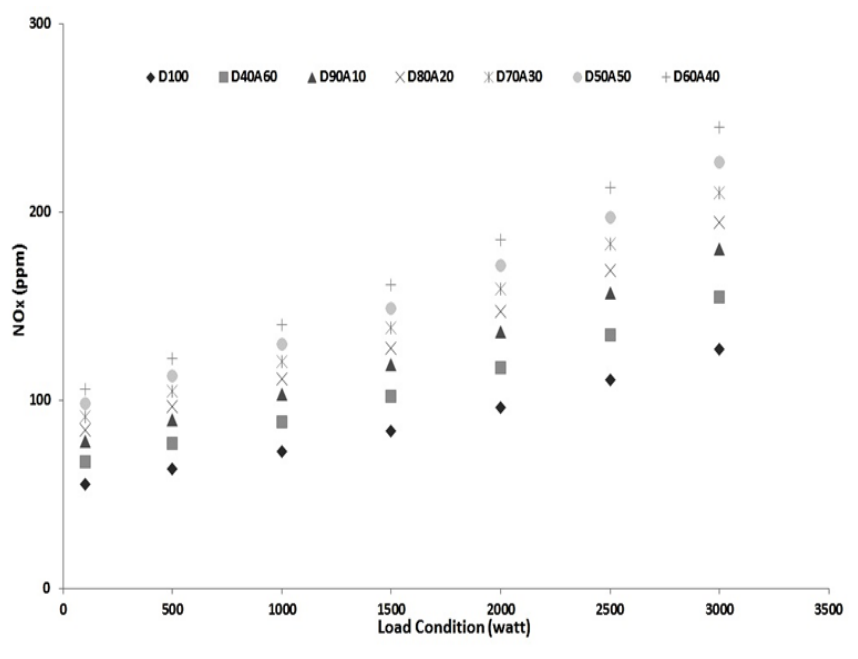

Figure 5. Variation in $\mathrm{NO}_{\mathrm{x}}$ emissions with varying load conditions

\section{CONCLUSIONS}

The performance and emission characteristics of sample biodiesel with variable engine loads have been scrutinized, analyzed and compared to that of conventional diesel. Total fuel consumption varies with the engine load. The specific fuel consumption reduced with engine loads. The power of the engine significantly increased with loads. The emission of oxides of nitrogen (NOx) from the sample biodiesel is higher than that of conventional diesel. The $\mathrm{CO} 2$ emission for sample biodiesel is bit higher than that of conventional diesel tested. From the above observations, it can be concluded that the performance of the average mixture sample biodiesel is better when compared with the conventional standard diesel for various loading condition. Also, there is a little increase in $\mathrm{NOx}$ and $\mathrm{CO} 2$ emission, but the trend is similar to conventional diesel fuel and falls in tolerable range.

\section{ACKNOWLEDGMENT}

The authors would like to gratefully acknowledge the MCKV Institute of Engineering (MCVIE) for their support in this research.

\section{REFERENCES}

[1] Rizwanul Fattah I.M., Masjuki H.H., Liaquat A.M., Ramli R., Kalam M.A., Riazuddin V.N., "Impact of various biodiesel fuels obtained from edible and nonedible oils on engine exhaust gas and noise emissions," Renew Sustain Energy Rev, vol. 18, pp. 552-67, 2013. DOI: $\underline{10.1016 / \text { j.rser.2012.10.036. }}$

[2] Yaakob Z., Mohammad M., Alherbawi M., Alam Z., Sopian K., "Overview of the production of biodiesel from waste cooking oil," Renew Sustain Energy Rev, vol. 18, pp. 184-93, 2013. DOI: 10.1016/j.rser.2012.10.016.

[3] Swaminathan C., Sarangan J., "Performance and exhaust emission characteristics of a CI engine fueled with biodiesel (fish oil) with DEE as additive," Biomass Bio-energy, vol. 39, pp. 168-74, 2012. DOI: 10.1016/j.biombioe.2012.01.001.

[4] Jaichandar S., Annamalai K., "Effects of open combustion chamber geometries on the performance of pongamia biodiesel in a DI diesel engine," Fuel, 2012. DOI: 10.1016/j.fuel.2012.04.004.

[5] Bari S., Roy M.M., "Prospect of rice bran oil as alternative to diesel fuel," in Fifth International Conference on Small Engines, Their Fuels And The Environment, pp. 31-36, 1995.

[6] Babu A.K., Devaradjane G., "Vegetable oils and their derivatives as fuel for CI engines - an overview," SAE 2003-01-0767.

[7] Ramdas A.S., Jayaraj S., Muraleedharan C., "Use of vegetable oils as IC engine fuel - A review," Renew Energy, vol. 29, pp. 727-42, 2004. DOI: 10.1016/j.renene.2003.09.008.

[8] Huang Jincheng, Wang Yaodong, Li Shuangding, Hongdong Anthony P., "Experimental investigation on the performance of a diesel engine fuelled with ethanol-diesel blends," Appl Therm Eng, vol. 29, pp. 2484-90, 2009.2 DOI: 10.1016/j.applthermaleng.2008.12.016

[9] Hazar Hanbey, Aydin Huseyin, "Performance and emission evaluation of a CI engine fuelled with preheated raw rapeseed oil (RRO)-diesel blends," Appl Energy, vol. 87, pp. 786-90, 2010. DOI: 10.1016/j.apenergy.2009.05.021.

[10] Balat Mustafa, Balat Havva, "Progress in biodiesel processing," Appl Energy, vol. 87, pp. 1661-9, 2010.

[11] Rao T. Venkateshwara, Rao G. Prabhakar, Reddy K. Hema Chandra, "Experimental investigation of pongamia, Jatropha, Neem methyl esters as biodiesel in CI engine," JJMIE, vol. 2, pp. 117-122, 2008.

[12] Suresh Kumar, Velraj R., Ganesan R., "Performance and emissions of a C.I engine fuelled with PPME and 
its blends with diesel," Renew Energy, vol. 82, pp. 1311-1325, 2008. DOI: 10.1016/j.renene.2008.01.011.

[13] Agarwal Avinash Kumar, Rajamanoharan K., "Experimental investigations of performance and emissions of Karanja oil and its blends in a single cylinder agricultural diesel engine," Appl Energy, vol. 86, pp. 106-112, 2009. DOI: 10.1016/j.apenergy.2008.04.008.

[14] Qi D.H., Chen H., Geng L.M., Bian Y.Z.H., Ren X.C.H., "Performance and emission characteristics of a biodiesel-diesel-methanol blend fuelled engine," Appl Energy, vol. 87, pp. 1679-1686, 2010. DOI: 10.1016/j.fuel.2011.11.015.

[15] Bhattacharyya, S., Seth, D.K., Ghosh, S., Pal, S., "Experimental Investigation of Performance And Emission Of CI Engine Using Additives-Fuel", ELK Asia Pacific Journals, Special Issue, ISBN: 978-81930411-8-5. 